Рязанцев Лев Васильович

Заслужений прачівник культури України, дочент,

Київський національний університет культури і мистецтв

Киів, Україна

l.ryazancev2016@gmail.com

\title{
РОЛЬ ВНУТРІШНЬОКАДРОВОЇ МУЗИКИ В КІНОФІЛЬМІ
}

Мета роботи. Проаналізувати роль внутрішньокадрової музики в кінофільмі в процесі організації звукового рішення фільму, виявити особливості застосування іiі в фільмах різних жанрів. Методологія дослідження передбачає застосування аудіовізуального аналізу зарубіжних та українських фільмів, що дозволить прийти до розуміння ролі внутрішньокадрової музики в кінофільмі. Наукова новизна дослідження полягає в тому, що чітко сформовано основні принципи застосування внутрішньокадрової музики в кінофільмі та показано ії вплив на звукове вирішення кінофільму. Висновки. Внутрішньокадрова музика $є$ фактором, що тісно пов'язаний з фабулою фільму, і є двигуном дії вперед. Найчастіше в ролі внутрішньокадрової музики виступала і виступає пісня, яка може дозволяти співакові освідчуватись у своїх почуттях, підкреслювати героїзм і мужність, будувати дію фільму. Танець - також дуже часто використовується внутрішньокадрово в різних фільмах, насмперед пов'язаних 3 народним побутом і національними особливостями. Танцювальна музика поєднує дуже різні епізоди, відображає і характеризує зміни часу в кадрі, $є$ прикладом співіснування та взаємовпливу різних музичних культур. Внутрішньокадрова інструментальна музика може бути і у вигляді великого концертного номера, і вести за собою зображальний монтаж сцени. А також музика ще й підкреслює і трагічні моменти фільму, і є драматично важливою музикою заднього плану, надає іронічний підтекст сцені, відіграє роль шпигунського шифру або паролю, може бути фоном, протилежним змісту кадру, і створювати наявний контраст 3 цим змістом.

Ключові слова: внутрішньокадрова музика, інструментальна музика, пісня, танець, кінофільм.

Рязанцев Лев Васильевич, Заслуженный работник культуры Украины, доиен, Киевский национальный университет культуры и искусств, Киев, Украина

\section{Роль внутрикадровой музыки в кинофильме}

Цель работы. Осуществить анализ роли внутрикадровай музыки при организации звукового решения фильма, выявить особенности применения ее в фильмах различных жанров. Методология исследования предполагает применение аудиовизуального анализа кинофильмов, что позволит перейти к пониманию роли внутрикадровай музыки в кинофильме. Научная новизна 
исследования состоит в том, что четко сформированы основные принципы применения внутрикадровой музыки в кинофильме и показано ее влияние на звуковое решение фильма. Выводы. Внутрикадровая музыка является фактором, тесно связанным с фабулой фильма, и двигателем действия вперед. Чаще всего в роли внутрикадровой музыки выступала и выступает песня, которая может разрешать певцу признаваться в своих чувствах, подчеркивать героизм и мужество, строить действие фильма. Танец - также очень часто используется внутри кадра в различных фильмах, прежде всего связанных с народным бытом и национальными особенностями. Танцевальная музыка объединяет очень разные эпизоды, отражает и характеризует изменения времени в кадре, является примером сосуществования и взаимовлияния различных музыкальных культур. Внутрикадровоя инструментальная музыка может быть в виде большого концертного номера и вести за собой изобразительный монтаж сцены. В другом случае она подчеркивает и трагические моменты фильма, и является драматично важной музыкой заднего плана, предоставляя иронический подтекст сцене, играет роль шпионского шифра или пароля, может быть фоном, противоположным содержанию кадра, создающим явный контраст с этим содержанием.

Ключевые слова: внутрикадровая музыка, инструментальная музыка, песня, танец, кинофильм.

Riazantsev Lev, Honored Worker of Culture of Ukraine, Associate Professor, Kyiv National University of Culture and Arts, Kyiv, Ukraine

\section{The role of source music in a motion picture}

The purpose of the article is to analyze the role of source music in a motion picture in the process of organizing its sound design; to reveal the features of its application in films of different genres. The research methodology consisted in the application of audiovisual analysis of foreign and Ukrainian movies, which allowed for understanding the role of source music in a motion picture. The scientific novelty of the work lies in the fact that the basic principles of using source music in a film were clearly formed and its impact on the sound design of the movie was shown. Conclusions. Source music is a factor that is closely related to the plot of the film and is its driving force. Most often, source music has been represented by a song that can let the singer express their feelings, emphasize heroism and courage, and build up the action of the movie. Dance is also frequently used as source music in various motion pictures, primarily those related to everyday life and national characteristics. Dance music combines very different episodes, reflects and characterizes changes in the time frame, acts as an example of the coexistence and mutual influence of different musical cultures. Instrumental source music can also be in the form of a large concerted item and lead a pictorial installation of the stage. Besides, it emphasizes tragic moments of the film and is dramatically important as background music; it provides the scene with an ironic subtext, plays the role of an espionage cipher or password; it may act as the background opposite to the content of the frame, and create an explicit contrast with this content.

Key words: source music, instrumental music, song, dance, motion picture. 
Вступ. Усі мистецтва, що існують у часі та просторі, так чи інакше пов'язані зі звуком i музикою. Найбільш суттєву роль музика відіграє в кінофільмах, телепрограмах, відеофільмах. Будь-яке художнє явище рано чи пізно створює свою власну теорію, що формує його основні проблеми, його естетичні та конструктивні принципи. У повній мірі це стосується й ролі внутрішньокадрової музики в кінофільмі.

Роль кіномузики в фільмі розглядалась С. Ейзенштейном ще на початку появи звукового кіно в працях «Будущее звукового фильма. Заявка» [7, с. 315317] i «Вертикальный монтаж». [7, с. 189-268]. Останнім часом ця тема розробляється сучасними авторами. Так, в монографії Горпенко В. Г. [2, с. 153187], яка присвячена проблемам режисури екранних мистецтв, в першому томі розглядаються перші крокі творчості С. Параджанова. Про значення кіномузики йдеться в розділі «Значення звукового ряду в кіно» у Зофії Лісси [4, с. 133-285], Маньковського В. С. [5, с. 28-49] в розділі «Особенности художественной передачи звука» аналізується роль музики в художніх фільмах. Розлогов К. Є. [3, с. 120-197] досліджує шляхи аудіовізуального синтезу. Ролі лейтмотивів присвячена стаття автора «Техніка лейтмотивів в кіномузиці» [6,124-130]. Треба підкреслити, що проблема ролі внутрішньокадрової музики в кінофільмі в наукових дослідженнях у всіх аспектах не достатньо висвітлена. Перед нами постає проблема, яку висуває практика звукового рішення фільму, тому потрібно детально зупинитися на проблемі ролі внутрішньокадрової музики в кінофільмі.

Мета статті - виявити роль внутрішньокадрової музики в кінофільмі під час процесу організації звукового вирішення фільму, проаналізувати особливості іiі застосування в різних фільмах та визначити способи їі реалізації.

Відповідно до мети статті були поставлені конкретні завдання, а саме:

- $\quad$ дослідити що саме внутрішньокадрова музика привносить у фільм;

- проаналізувати, які значення може виконувати внутрішньокадрова музика у фільмі;

- $\quad$ систематизувати матеріал і сформулювати систему понять про роль внутрішньокадрової музики в фільмі.

Виклад основного матеріалу. Спочатку уточнимо поняття закадрової та внутрішньокадрової музики. «Іноді кажуть, що музика прийшла в кіно, коли воно було ще німим - на тій підставі, що перегляд фільмів супроводжувався акомпанементом - переважно грою на фортепіано, часом - супроводом оркестру або навіть відтворенням механічного запису музики (грамофон, оркестр тощо). Музика була частіше частиною демонстрації фільму, a не самого кінотвору. То було намагання компенсувати природжену німоту. У кіно музика ввійшла пізніше - із винайденням більш-менш досконалих засобів фіксації звуків під час фільмування картин і їх належного відтворення під час демонстрації. Зрима музика увійшла в кіно спочатку як і все інше: як об'єкт зображення, предмет кінофотографування. Це явище видавалося цікавим саме собою: німі досі зображення раптом зазвучали. Перші музичні фільми і були наслідком саме такої можливості: «Співак джазу» (1927 р.) реж. А. Крос- 
ленда, «Співаючий йолоп» (1928 р.) реж. Л. Бекона - обидва за участю американського співака О. Джонсона, «Простаки 3 Парижа» (1929 р.) реж. Р. Уоллеса за участю французького співака М. Шевальє.

Незабаром, 3 удосконаленням технічних засобів поєднання звуку і зображення, роль музики у кіно ніби роздвоюється. Крім того, що вона, як і раніше, залишається об'єктом зображення, вона стає ще й засобом зображення. Спочатку закадровим (музика посилює певну емоційну атмосферу, відтворювану на екрані), - а згодом і внутрішньокадровим (музика стає одним iз засобів характеристики тих чи інших персонажів). Найчастіше у ролі внутрішньокадрової музики виступала i виступає пісня, закадрової інструментальна оркестровка» [1, с. 172 - 173].

У даному дослідженні розглядається роль внутрішньокадрової музики на прикладах художніх фільмів, де музика зображується у виконанні самих персонажів, вона звучить для учасників зображуваної дії, вони іiі чують. У даному випадку музика є фактором, тісно пов'язаним з фабулою фільму, і двигуном дії вперед. Прикладом цього може бути український радянський художній фільм Сергія Параджанова «Українська рапсодія» - який був відзнятий на Київській кіностудії імені Олександра Довженка в 1961 р. Текст пісень - Микола Нагнибіда, композитор - Платон Майборода.

У роки війни поранений Антон (Едуард Кошман) потрапляє в полон. Під час втечі з-під конвою йому допомагає німецький органіст Вайнер, переховуючи у себе в будинку. Тим часом його кохана дівчина - Оксана Марченко (Ольга Петренко - піі пісні лунають голосом Євгенії Мірошниченко), співачка 3 українського села, не втратила надію на його повернення. Настали мирні дні. Оксана, володарка прекрасного голосу, виступаючи на Всесвітньому конкурсі вокалістів, завойовує Гран-прі. Але перемога не приносить їй повного щастя. Вона не може забути з коханим, бо їх ії розлучила війна.

Розглянемо декілька епізодів, в яких музика застосовується як внутрішньокадрова. В епізоді проведення музичного конкурсу зображено перипетії боротьби співачок, які пристрасно бажають перемоги.

Спів конкурсанток - арії:

- $\quad$ Слизавети - «Дон Карлос» Дж. Верді;

- $\quad$ Віолетти - «Травіата» Дж. Верді;

- $\quad$ «Алілуя»- В. А. Моцарта;

- $\quad$ Лючії - «Лючія ді Ламмермур Г. Доніцетті.

Епізод завершується врученням Оксані диплома та позаконкурсним виконанням Оксаною української пісні «Зоре моя вечірняя» на вірші Тараса Григоровича Шевченка:

Зоре моя вечірняя,

Розкажи, як за горою

Зійди над горою,

Поговорим тихесенько

В неволі з тобою.

Сонечко сідає,

Як у Дніпра веселочка

Воду позичає

Кадри iї співу поєднано 3 кадрами квітучого саду часів Оксаниного дитинства, лелеки, що сідає в гніздо на хатній стрісі. Оксана подає дідові 
бандуру, слухає виконання ним цієї пісні, підспівує йому. Головне тут - як впливає українській спів на дитячу душу.

У наступному епізоді з'являється драматургічний антагоніст - Вадим (Юрій Гуляєв), який вступає в боротьбу за любов Оксани. На сільському святі він виконує романс Миколи Римського-Корсакова «Не ветер, вея с высоты», текст якого дозволяє співакові освідчитись їй у своїх почуттях:

Не ветер, вея с высоты,

Листов коснулся ночью лунной-

Моей души коснулась ты:

Она тревожна, как листы,

Она, как гусли, многострунна!

Юрій Гуляєв співає і грає, передаючи не лише голосові, а й психологічні ознаки симпатії до Оксани.

В епізодах війни музикою підкреслюється героїзм i мужність українського народу в боротьбі з загарбниками:

- $\quad$ Вадим співає в госпіталі «Безмежнеє поле» Миколи Лисенка;

- $\quad$ в зруйнованому театрі, поранений Антон диктує листа Оксані, а в цей час в кадрі виконується бійцем «Місячна соната» Людвіг ван Бетховена;

- $\quad$ поранений Антон потрапляє в полон, в товарному вагоні поїзда він і полонені співають такі пісні: «Реве та стогне», «Розпрягайте, хлопці, коней».

Оксана виступає 3 піснею Сольвейг Эдварда Гріга перед бійцями на передовій. Вона не втрачає надії на повернення свого коханого:

Зима пройдет, И весна промелькнет, Увянут все иветь, Снегом их заметет; И ты ко мне вернешьс, - Мне сердие говорит; Тебе верна останусь, Тобой лишь буду жить.

Після війни Оксана повертається до занять у консерваторії. У кадрі зображено як вона виконує арії:

- $\quad$ Прилепи - «Пікова дама» П. Чайковсько;

- $\quad$ Людмили - «Руслан і Людмила» М. Глінки;

- $\quad$ Віолетти - «Травіата» Дж. Верді;

- $\quad$ Лакме - «Лакме» Л. Деліба;

- $\quad$ Оксани - «Запорожець за Дунаєм» С. ГулакаАртемовського.

Ці й інші приклади свідчать про цілеспрямованість рішення, яке включає в структуру фільму такий компонент як пісня. Це не дивно - йдеться про долю співачки.

«Зрозуміло, що саме музика організовує зображення. Музична драматургія бере на себе основну формотворчу місію. Як 3 точки зору змістовно-сематичної, так і композиційно-драматургічної. Вона виражає задум. Задум режисерський, який передбачає певне чергування певних подій, певним чином виражених» [2, с. 182]. Так вважає відомий український режисер теоретик кіно Володимир Горпенко.

Часто дія художнього фільму будується навколо однієї пісні. Першим фільмом такого плану була знаменита картина Рене Клера «Під дахами Парижа», 1930 р. Пісня в стилі вальсу, написана Раулем Моретті, на слова Рене 
Назелле. Ї̈̈ спочатку виконує в провулку вуличний співак, який ходить по всьому кварталу, пісню різними голосами співають, насвистують, повністю або шматочками, все нові й нові персонажі фільму: консьєржка, вистукуючи мотив одним пальцем на піаніно, іiі співає, розчісуючи волосся, якась жінка, іiі співають закохані тощо. Пісня перетворюється на символ паризької вулиці, кварталу, в фактор, що поєднує між собою епізоди фільму.

Таку ж роль відіграє і «Пісня про рушник» в українському фільмі «Літа молодії», 1958 р. (режисер Олексій Мішурін, композитор Платон Майборода, текст пісень Андрія Малишка.)

Танець - музичний жанр, який дуже часто використовується внутришньокадрово в різних фільмах. Насамперед, танцювальна музика тісно пов'язана $з$ народним побутом, відображає національні особливості тощо. Це яскраво зображено в українських фільмах: «Тіні забутих предків» (режисер Сергій Параджанов, композитор Мирослав Скорік), «Білий птах 3 чорною ознакою» (режисер Юрій Іллєнко, музика Іван Миколайчук).

Танець завжди пов'язаний з художнім рухом. В естетично осмислених рухах людина може дуже багато чого розповісти. Наприклад, епізод з фільму «Запах жінки» 1992 р., в якому сліпий підполковник Френ Слейд (Аль Пачіно) вчить юну дівчину (Габріель Анвар) танцювати танго в ресторані, зворушить будь-кого до глибини душі. Аль Пачіно і Анвар проводили репетиції танцю протягом двох тижнів під популярне танго «Por una cabeza» (Всього на голову), яке написано в 1935 р. Карлосом Гарделя і Альфредо Ле Пера (режисер фільму Мартин Брест, композитор Томас Ньюман. Аль Пачіно за акторську роботу в цій стрічці отримав премії «Оскар» $\mathrm{i}$ «Золотий глобус».

Фільм «1+1» - французький трагікомедійний фільм 2011 року, який заснований на реальних подіях про успішного аристократа Філіпа (Франсуа Клюзе), який в наслідок нещасного випадку опиняється в інвалідному візку і бере собі в помічники молодого жителя передмістя Парижа, Дрісса (Омар Ci), який щойно звільнився з в'язниці і як найменше підходить для цієї роботи. У наслідок цього відбувається зіткненя двох культур: західноаристократичної та афро-іммігрантської. В епізоді Дня народження, Філіп просить камерний оркестр зіграти фрагменти 3 творів Баха, Вівальді, Римського-Корсакова для Дрісса, але він іронізує 3 цього приводу, стверджуючи, що це музика з мультиків і рекламних роликів. Тут він має рацію, класичну музику нещадно експлуатують в рекламі. I на противагу пропонує свою музику: - Тепер моя черга. То була Ваша класика, тепер буде моя. Група «Earth, Wind \& Fire» (Земля, Вітер і Вогонь). Заиініть. Це чума. I залучає манерних гостей до запального танцю:

Таниюй, чудова краӥна бугі!

Танцюй, чудова країна бугі!

Виповнюється фанк-композиція - Boogie Wonderland (Чудова краӥна бугі): Це приклад співіснування та взаємовпливу різних музичних культур.

Цікава роль музики у фільмі «Чорний Орфей», 1959 р. (режисер Марсель Камю, композитори Луїс Бонфа та Антоніу Карлос Жобін). «Золота пальмова 
гілка» Канського кінофестивалю 1959 р. і премія «Оскар» за кращий фільм іноземною мовою 1960 р.

Час щорічного карнавалу. Сдина пора року, коли можна без будь-яких обмежень і самоконтролю віддаватися веселощам, музиці і танцям. Протягом майже всього фільму «барабанить» танцювальна музика. Часом нашого вуха досягають лише їі віддалені звуки, в інших місцях вона лунає в повну силу. Це - реальна танцювальна музика, яка грає під час великого карнавалу в Ріо-деЖанейро, в якому бере участь, головним чином, негритянське населення, яке танцює на вулицях. Всі, без винятку, охоплені танцювальним божевіллям, і невпинний дріб барабана, навіть дуже часто заглушає мелодію, служить не тільки акомпанементом танців, а й ніби символом одержимості, загальної оргії танцю. До того ж ця танцювальна музика поєднує дуже різні епізоди цілого, але при цьому сама майже не змінюється. Те що музика використовується в цій ролі свідомо, доводить той факт, що в сценах, де на перший план виступають долі окремих людей, вона теж індивідуалізується: Орфей грою і співом заколисує свою кохану, йому намагаються наслідувати хлопчаки та дівчата.

У фільмі «Години надії», 1955 р. (режисер Ян Рибковський, композитор Анджєй Марковський) подібну роль виконує музика джаз-ансамблю, що грає на американській вантажівці, коли вона в’іжджає в звільнений табір. Здалеку чути наполегливий ритм цієї збудливої музики. Звуки наростають, наближаються, поки в кадр не в’їжджає вантажівка, на якій знаходяться піаніно i джазовий ансамбль. Тепер хвилю шаленого ритму підхоплють, скупчені в строкатий натовп, колишні в'язні табору. У божевіллі танцю вони дають волю усім почуттям, пригнобленими роками. Тут звучить звичайнісінька джазова музика, але в даній ситуації її роль значно ширше. Гримить рояль, заливається флейта-пікколо, в божевіллі танцю носяться люди. Музика то наближається, то віддаляється під барабанний ритм. Вона все ще звучить і коли танки нацистів прокладають собі шлях крізь танцюючий табір.

«Бал» (режисер Етторе Скола) - це унікальна музична картина, відзнята без єдиної репліки. Музика, міміка і пластика замінили в ній інші види вираження почуттів, думок і емоцій. Відзнятий в 1983 р., фільм охоплює період часу від тридцятих років до сучасності. Всі події відбуваються в танцювальному залі, але він з роками змінюється. Кожен актор грає по кілька персонажів, багато з яких проходять шлях п'ятдесятирічної історії разом з глядачем, інші ж з'являються в окремих епізодах.

Шість новел розповідають про перемогу народного фронту - 1936 р., Другу світову війну - 1940., окупацію Парижа - 1944 р., колоніальними зіткненнями - 1956 р., студентськими бунтами - 1968 р. і 1983 р. - час створення фільму. Все це наповнене посиланнями на поп-культуру, танцювальну музику кожного періоду. Історія Франції віддзеркалюється в тому, що відбувається в стінах залу. Його мешканці реагують на зміну модних течій і музичних стилів. Їх рухи в танці йдуть в ногу з часом, одяг i зачіски відповідають останнім на той час віянням. Роль музики в цьому фільмі, крім усього іншого, - відображати і характеризувати зміни часу в кадрі. 
Внутрішньокадрова музика також може бути i у вигляді великого концертного номера, як у фільмі «Людина, яка занадто багато знала», 1956 p. Це - шпигунський трилер Альфреда Хічкока, композитор Бернард Херрманн. Ключова фраза фільму - «скоро в лондонському Альберт-холі буде скоєно вбивство». Тому кульмінаційна сцена фільму відбувається в концертному залі Альберт-хол, де протягом 12 хв. виконується кантата «Штормова хмара» (Storm Cloud), яка написана спеціально для виконання на сцені концерту композитором Артуром Бенджаміном. Музична структура кантати: експозиція, розвиток і кульмінація - веде за собою зображальний монтаж сцени. Також, велику роль у розвитку сюжету відіграє пісня «Whatever Will Be, Will Be» (Що $б$ не сталося) у виконанні Джо (Доріс Дей). Слова пріспіву пісні:
Que será, será
Whatever will be, will be
Що буде, те й буде.
The future's not ours to see
Що б не сталося
Que será, será
Нам не дано знати
What will be, will be ...
майбутнього.
Що буде, те й буде, Що буде, те й буде...

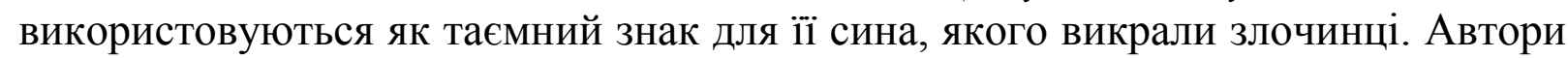
пісні Джей Лівінгстон і Рей Еванс отримали за неї премію «Оскар».

Музика в кадрі може бути пов'язана 3 трагічними моментами, як в польському фільмі «Канал», 1957 р. (режисер Анджей Вайда, композитор Ян Кренц ). Фільм оповідає про трагічну долю групи бійців Армії Крайової під час Варшавського повстання 1944 р., які намагаються залишити центр Варшави через каналізаційні канали. За сюжетом композитор, що знаходиться серед учасників повстання, пробує імпровізувати на роялі, щоб висловити своє бачення навколишньої дійсності. Коли повстанці опинилися в темряві каналізаційної системи, він, не витримуючи психічного й фізичного навантаження, несподівано починає грати на окарині, що підсилює трагічність ситуації.

Як драматично важлива, функціонує музика заднього плану в сцені зустрічі ватажків повстання в фільмі «Юність Шопена», 1952 р. (режисер Олександр Форд, композитор Казімеж Сероцький). Шопен, сам не приймає участі в зборах, грає в сусідній кімнаті свій полонез c-moll. Музика то посилюється в драматичні моменти дискусії, то звучить слабше, але за своїм змістом бере участь в дискусії молодих патріотів, хоча й лунає, у віддаленій, непоказаній частині кінопростору.

У фільмі «Незакінчена п’єса для механічного піаніно», 1977 р. (режисер Микита Михалков, композитор Едуард Артемьєв) показано, як в садибі генеральської вдови дворовий Захар виконує на піаніно Другу угорську рапсодію Ференца Ліста. Усі здивовані. Але як з'ясувалося, грало механічне піаніно. Ця музика надає іронічний підтекст сцені, яку вона супроводжує, але при цьому не перестає бути музикою, що виконується в кадрі.

Дуже цікаво використана внутрішньокадрова музика в якості шпигунського шифру в фільмі «Леді зникає», 1938 р. (режисер Альфред Хічкок, композитор Луїс Лівай,). 3'ясовується, що міс Фрой зовсім не та, за 
кого вона себе видає. Їй доручено передати закодовану інформацію у вигляді музичної композиції в британську розвідку.

Банальну пісеньку як сигнал, як «пароль» зустрічаємо в італійському фільмі «Рим - відкрите місто», 1946 р. (режисер Роберто Росселіні, композитор Ренцо Росселіні). Коли священик зустрічається 3 представником руху опору і віддає йому зібрані гроші, він впізнає революціонера тільки за пісенькою, яку той насвистує, стоячи на мосту. Тут музика, не перестаючи бути банальною, виконує одночасно важливу драматургічну роль.

Часто музика існує як відтворення звукозапису (транслюється по радіо, телевізору або звучить з платівки). Зазвичай, вона виконує роль музичного фону. У фільмі «Дівиця Розмарі», 1958 р. (режисер Рихард Тіле, композитор Ханс Шульц) в сцені, де дівчину вбивають, а по радіо в цей момент, в тій же кімнаті, лунає запальна танцювальну музику. Тут музика - фон, протилежний змісту кадру, і завдання музики - створити наявний контраст 3 цим змістом.

Наукова новизна дослідження в тому, що вперше сформульовані основні поняття ролі внутрішньокадрової музики в кінофільмі та відображено їх вплив на звукове вирішення кінофільму.

Теоретична значущість статті полягає в тому, що вона допомагає узагальнити інформацію про роль внутрішньокадрової музики в кінофільмі та сприяє розвитку музичної культури.

Практична значущість дослідження полягає в тому, що воно може бути використане при музичному оформлені кінофільму та в програмах підготовки звукорежисерів.

У результаті нашого дослідження маємо такі висновки:

- внутрішньокадрова музика є фактором, що дуже тісно пов'язаний з фабулою фільму, і двигуном дії вперед. Найчастіше у ролі внутрішньокадрової музики виступала і виступає пісня, яка може дозволяти співакові освідчуватись у своїх почуттях, підкреслювати героїзм і мужність, будувати дію фільму;

- танець - також дуже часто використовується внутрішньокадрово в різних фільмах, насамперед пов'язаних з народним побутом і національними особливостями. Танцювальна музика поєднує дуже різні епізоди, відображає і характеризує зміни часу в кадрі, є прикладом співіснування та взаємовпливу різних музичних культур;

- $\quad$ внутрішньокадрова інструментальна музика може бути і у вигляді великого концертного номера і вести за собою зображальний монтаж сцени. А ще вона підкреслює і трагічні моменти фільму, i $є$ драматично важливою музикою заднього плану, надає іронічний підтекст сцені, відіграє роль шпигунського шифру або паролю, може бути фоном, протилежним змісту кадру, і створювати наявний контраст з цим змістом.

\section{Список використаних джерел}

1. Безклубенко С. Д. Мистецтво: терміни та поняття. В 2т. Т.1. / С. Д. Безклубенко. - Київ : Майстер-Принт, 2008. - 255с. 
2. Горпенко В. Г. Архітектоніка фільму: Режисерські засоби і способи формування структури екранного видовища. В 5т. Т.1 / В. Г. Горпенко. - Київ : ДІТМ, 2000. - 145c.

3. Введение в экранную культуру: новые аудиовизуальные технологии : учеб. пособие / отв. ред. К. С. Розлогов. - Москва : Искусство, 2005. - 480с.

4. Лисса 3. Эстетика киномузыки пер. с нем. / 3. Лисса. - Москва : Музыка, 1970. - 495с.

5. Маньковський В. С. Основы звукооператорской роботы : учеб. пособие / В. С. Маньковський - Москва : Искусство, 1984. - 240с.

6. Рязанцев Л. В. Техніка лейтмотивів в кіномузиці / Л. Рязанцев // Вісник КНУКіМ. Серія : Мистецтвознавство. - Київ, 2015.- Вип. 33. - С. 124- 130.

7. Ейзенштейн С. М. Избранные произведения В 5 т. Т. 2. Монтаж/ Ейзенштейн С. М. - Москва : Искусство, 1964. - 549 с.

\section{References}

1. Bezklubenko, S. (2008). Art: terms and concepts. Vol. 2. Kyiv: MaisterPrint.

2. Horpenko, V. (2000). Architectonics of the film: directorial means and methods of forming the structure of the on-screen work. Vol. 1. Kyiv: Kyiv State Institute of Theatrical Art.

3. Rozlogov, K. (ed). (2005). Introduction to Screen Culture: New Audiovisual Technologies. Moscow: Iskusstvo.

4. Lissa, Z. (1970). Aesthetics of Chinese music. Moscow: Muzika.

5. Mankovsky, V. (1984). Fundamentals of Sound Operator's Work. Moscow: Iskusstvo.

6. Riazantsev, L. (2015). Technique of leitmotifs in cinematic music. Visnyk KNUKiM. Seriia : Mystetstvoznavstvo [Kyiv National University of Culture and Arts], issue 33, hh. 124-130

7. Eyzenshteyn, C. (1964). Selected Works. Vol. 2. Moscow: Iskusstvo.

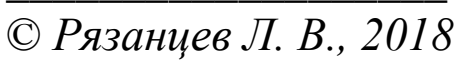

